\title{
Recent changes in the number of rainfall events related to debris-flow occurrence in the Chenyulan Stream Watershed, Taiwan
}

\author{
J. C. Chen ${ }^{1}$, W. S. Huang ${ }^{2}$, C. D. Jan ${ }^{2}$, and Y. H. Yang ${ }^{1}$ \\ ${ }^{1}$ Dept. of Environmental and Hazards-Resistant Design, Huafan University, New Taipei, Taiwan \\ ${ }^{2}$ Dept. of Hydraulic and Ocean Engineering, National Cheng Kung University, Tainan, Taiwan
}

Correspondence to: J. C. Chen (jinnchyi@cc.hfu.edu.tw)

Received: 21 March 2011 - Revised: 10 January 2012 - Accepted: 17 January 2012 - Published: 21 May 2012

\begin{abstract}
This study analyzed the variability in the number of rainfall events related to debris-flow occurrence in the Chenyulan stream watershed located in central Taiwan. Rainfall data between 1970 and 2009 measured at three meteorological stations nearby/in the watershed were collected and used to determine the corresponding regional average rainfall for the watershed. Data on debris-flow events between 1985 and 2009 were collected and used to study their dependence on regional average rainfall. The maximum 24-h regional rainfall $R_{\mathrm{d}}$ was used to analyze the number of rainfall events $N_{\mathrm{r}}$, the number of rainfall events that triggered debris flows $N_{\mathrm{d}}$, and the probability of debris-flows occurrences $P$. The variation trends in $N_{\mathrm{r}}, N_{\mathrm{d}}$ and $P$ over recent decades under three rainfall conditions $\left(R_{\mathrm{d}}>20,230\right.$, and $580 \mathrm{~mm}$ ) related to debris-flow occurrence were analyzed. In addition, the influences of the Chi-Chi earthquake on $N_{\mathrm{d}}$ and $P$ were presented. The results showed that the rainfall events with $R_{\mathrm{d}}>20 \mathrm{~mm}$ during the earthquakeaffected period (2000-2004) strongly responded to the increases in the average number of rainfall events that triggered debris flows and the average probability of debris-flows occurrences. The number of rainfall events with $R_{\mathrm{d}}>230 \mathrm{~mm}$ (the lower boundary for the rainfall ever triggering debris flow before the Chi-Chi earthquake), and $R_{\mathrm{d}}>580 \mathrm{~mm}$ (the lower boundary for extreme rainfall ever triggering numerous debris flows) in the Chenyulan stream watershed increased after 2000. The increase in the number of extreme rainfall events with $R_{\mathrm{d}}>580 \mathrm{~mm}$ augmented the number of rainfall events ever triggering numerous debris flows in the last decade. The increase in both the number of rainfall events that ever triggered debris flows and the probability of debrisflow occurrences was greater in the last decade (2000-2009) than in 1990-1999.
\end{abstract}

\section{Introduction}

Over the past few decades, global climate change has caused a series of changes (Katz and Brown, 1992; IPCC, 1996; Bryant, 1997), including increase in precipitation and temperature and more frequent natural disaster events; climate change has become one of the world's most critical issues. Some previous studies have examined the impact of climate change on debris-flow activity in mountainous areas. For example, Zimmermann and Haeberli (1992) analyzed the relationship between climate variation and debris flows in the Swiss Alps. Rebetez et al. (1997) recorded debris-flow events in Ritigraben in the Swiss Alps, and studied the longterm impact of temperature and rainfall fluctuations on the frequency of debris-flow events. Jomelli et al. (2004) analyzed the effects of climate change on the frequency and altitude of debris-flow events in recent decades in Dévoluy and Ecrins in the French Alps. Stoffel (2007) investigated the variability that may be caused in debris-flow occurrence under future greenhouse climate conditions in the area of Ritigraben in the Alps. These studies showed some relationships between debris-flow triggers and (1) an increase in the number of intense rainfall events and/or (2) glacier retreat and permafrost degradation due to an increase in temperatures. However, the hydrologic response of debris flows to climate is complex (Jakob and Lambert, 2009). The relationships between rainfall changes and debris-flow occurrences differ regionally since there are differences in regional responses to global climate change. Rainfall change generally responds to variations in the number of specified rainfall events with rainfall amount greater than a certain threshold. The present study investigated the relationship between the variability in specified rainfall events and debris-flow occurrence in the Chenyulan stream watershed, where many debris-flow events have been recorded since 1985 . One objective of this work 
was to understand variations in regional rainfall characteristics, such as the number of rainfall events for a certain rainfall amount, and their relation to debris-flow occurrences in the Chenyulan stream watershed in recent decades; the second objective was to determine whether the number of rainfall events that triggered debris flows and the probability of debris-flow occurrences in the Chenyulan stream watershed were affected by variations in regional rainfall characteristics. Furthermore, empirical relationships were presented for the average annual number of rainfall events triggering debris flows and the probability of debris-flow occurrences relative to the average annual number of rainfall events in the past decades. The results of this study can provide a scientific basis for the long-term forecast and prevention of debris flows.

\section{Debris flows in the Chenyulan stream watershed}

The Chenyulan stream watershed, located in Nantou County in central Taiwan, has a catchment area of $449 \mathrm{~km}^{2}$, a main stream length of $42 \mathrm{~km}$, a mean stream gradient of $4^{\circ}$, and elevations between 310 and $3952 \mathrm{~m}$. The Chenyulan stream follows the Chenyulan Fault, a boundary fault dividing two major geological zones of Taiwan. In addition to the boundary fault, the Chenyulan stream watershed also contains many other faults accompanied by fracture zones. Consequently, fractured rock masses prevail within the study area, accounting for enormous landslides and providing an abundant source of rock debris for debris flows (Lin and Jeng, 2000). The annual rainfall in the watershed ranges from $2000 \mathrm{~mm}$ to $5000 \mathrm{~mm}$, with an average value of approximately $3500 \mathrm{~mm}$. Approximately $80 \%$ of the annual rainfall in the watershed occurs between May and October, especially during typhoons. Debris-flow hazards are common within the watershed, owing to the combination of weak geological conditions, heavy rainfall, and accompanying frequent earthquakes. Several debris-flow events in this watershed have been studied or documented (Lin and Jeng, 2000; Chang et al., 2001; Cheng et al., 2005; Jan and Chen, 2005; Chen and Jan, 2008; Chen et al., 2009; Chen, 2011; Chen et al., 2011). The present study utilized hydroclimatic data for events inducing debris flows from 1985 to the end of 2009.

Thirty-six rainfall events, including 18 rainstorms and 18 typhoon-induced heavy rainfall events, have caused debris flows in the Chenyulan stream watershed, as listed in Table 1. Notably among these, heavy rainfall events were associated with Typhoon Herb in 1996, Typhoon Toraji in 2001, and Typhoon Morakot in 2009. Typhoon Herb struck Taiwan between 31 July and 1 August 1996. The typhoon caused an unexpectedly high cumulative rainfall (up to $1994 \mathrm{~mm}$ within 2 days, measured at Alisan rainfall station near the headwater of the watershed) and caused over thirty debris-flows (Jan and Chen, 2005); 27 people were declared dead and 14 missing. The 1999 Chi-Chi earthquake with a moment magnitude
$M_{\mathrm{w}}=7.6$, on 21 September 1999, was the largest in Taiwan for $50 \mathrm{yr}$ and the largest on the Chelungpu thrust fault in 300-620 yr (Shin and Teng, 2001; Chen et al., 2001; Dadson et al., 2004; Huang et al., 2001) and caused significant effects on the watershed. After the Chi-Chi earthquake, the extremely heavy rains brought by Typhoons Toraji and Nali in 2001 caused numerous debris flow events in central Taiwan (Cheng et al., 2005), and resulted in over 100 people dead or missing and major damage to houses, roads, bridges, and dikes. In August 2009, Typhoon Morakot brought heavy rainfall with an hourly rainfall up to $123 \mathrm{~mm}$ and a 48 -h cumulative rainfall up to $2361 \mathrm{~mm}$, as measured at Alisan rainfall station. It caused many debris flow events and other damage such as failure of river embankments, collapsed bridges, buried houses, and damage to numerous sections of Highway Route 21. In Shenmu and Tongfu villages in Xinyi Township, over 20 houses were buried by debris flows or washed away by floods. Numerous debris-flow events triggered by rainstorms and typhoons between 1985 and 2009 (as listed in Table 1) provide an opportunity to study the variability in the number of specified rainfall events associated with debrisflow occurrences in the Chenyulan stream watershed.

\section{Regional average rainfall in the Chenyulan stream watershed}

The trend in regional rainfall characteristics in the Chenyulan stream watershed needs to be studied by estimating the long-term record of rainfall data. As shown in Fig. 1, there are three meteorological stations - Sun Moon Lake, Yushan, and Alisan - near/within the Chenyulan stream watershed where rainfall data series have been collected for more than $40 \mathrm{yr}$ (since 1970). Therefore, the hourly rainfall data collected from these three stations between 1970 and 2009 were used to estimate the regional average rainfall $\bar{p}$ for the watershed by using the reciprocal-distance-squared method (Chow et al., 1988). Since this method is simple and can directly reflect the weighting of distance, it has been widely used not only in determining ungauged or regional average rainfalls but also in determining unmeasured or regional average physical quantities in other fields, such as hydrology and earth science (Ashraf et al., 1997; Cheng, 1998; Teegavarapu and Chandramouli, 2005; Chen, 2011). The regional average rainfall estimated by the reciprocal-distance-squared method can be expressed as follows:

$\bar{p}=\sum_{i=1}^{3} w_{i} p_{i}$

where $p_{i}$ is the rainfall record from meteorological stations, and $i=1,2$, or 3 represents the Sun Moon Lake, Yushan, or Alisan meteorological stations, respectively; $w_{i}$ is the weighting factor corresponding to $p_{i}$. The weighting factor is expressed as $w_{i}=d_{i}^{-2} / \sum_{i=1}^{3} d_{i}^{-2}$, where $d_{i}$ is the distance 
Table 1. Debris-flow events and related rainfall characteristics in the Chenyulan stream watershed between 1985 and 2009.

\begin{tabular}{|c|c|c|c|c|c|c|c|c|}
\hline Year & $\begin{array}{r}\text { Date of } \\
\text { rainy } \\
\text { event }\end{array}$ & $\begin{array}{l}\text { Name of } \\
\text { rainy } \\
\text { event }\end{array}$ & $\begin{array}{r}\text { Number of } \\
\text { debris flows } \\
N\end{array}$ & $\begin{array}{r}\text { Maximum } \\
\text { hourly rainfall, } \\
I_{\mathrm{m}}\left(\mathrm{mm} \mathrm{h}^{-1}\right)\end{array}$ & $\begin{array}{r}\text { Maximum } \\
\text { 24-h rainfall, } \\
R_{\mathrm{d}}(\mathrm{mm})\end{array}$ & $\begin{array}{l}\text { Total } \\
\text { rainfall, } \\
R(\mathrm{~mm})\end{array}$ & $\begin{array}{r}\text { Rainfall } \\
\text { duration, } \\
T(\mathrm{~h})\end{array}$ & $\begin{array}{r}\text { Mean rainfall } \\
\text { intensity, } \\
I\left(\mathrm{~mm} \mathrm{~h}^{-1}\right)\end{array}$ \\
\hline 1985 & 23-25 Aug & Typhoon Nelson & $>2$ & 47.2 & 418.8 & 565.4 & 50.0 & 11.3 \\
\hline 1986 & 21-22 Aug & Typhoon Wayne & $>2$ & 50.8 & 329.8 & 329.8 & 18.0 & 18.3 \\
\hline 1992 & 30-31 Aug & Typhoon Polly & $>1$ & 41.3 & 479.5 & 560.9 & 41.0 & 13.7 \\
\hline 1996 & 31 Jul-1 Aug & Typhoon Herb & $>30$ & 71.6 & 1181.6 & 1356.0 & 35.0 & 38.7 \\
\hline 1998 & $7-8$ Jun & Rainstorm & 3 & 28.1 & 227.8 & 317.6 & 40.0 & 7.9 \\
\hline 1998 & 4-5 Aug & Typhoon Otto & 4 & 64.6 & 311.7 & 311.7 & 19.0 & 16.4 \\
\hline 1998 & $15-16$ Oct & Typhoon Zeb & 2 & 24.6 & 251.0 & 288.8 & 31.0 & 9.3 \\
\hline 1999 & 27-28 May & Rainstorm & 2 & 24.3 & 254.3 & 305.7 & 32.0 & 9.6 \\
\hline 2000 & $1 \mathrm{Apr}$ & Rainstorm & 2 & 20.0 & 75.1 & 75.1 & 8.0 & 9.4 \\
\hline 2000 & $25 \mathrm{Apr}$ & Rainstorm & 1 & 8.4 & 30.6 & 30.6 & 9.0 & 3.4 \\
\hline 2000 & 28-29 Apr & Rainstorm & 1 & 7.9 & 78.2 & 78.2 & 14.0 & 5.6 \\
\hline 2000 & 2 May & Rainstorm & 1 & 8.1 & 30.6 & 30.6 & 5.0 & 6.1 \\
\hline 2000 & 12-14 Jun & Rainstorm & 4 & 18.0 & 228.1 & 354.0 & 47.0 & 7.5 \\
\hline 2000 & $18 \mathrm{Jul}$ & Rainstorm & 3 & 12.7 & 30.0 & 30.0 & 3.0 & 10.0 \\
\hline 2000 & $22 \mathrm{Jul}$ & Rainstorm & 3 & 16.3 & 20.7 & 20.7 & 2.0 & 10.4 \\
\hline 2000 & $5 \mathrm{Aug}$ & Rainstorm & 4 & 11.6 & 38.8 & 38.8 & 10.0 & 3.9 \\
\hline 2000 & 22-23 Aug & Typhoon Bilis & 2 & 20.6 & 234.5 & 234.5 & 24.0 & 9.8 \\
\hline 2001 & 5 Jun & Rainstorm & 1 & 7.5 & 27.0 & 27.0 & 8.0 & 3.4 \\
\hline 2001 & 14-15 Jun & Rainstorm & 3 & 18.4 & 200.1 & 200.1 & 24.0 & 8.3 \\
\hline 2001 & 29-30 Jul & Typhoon Toraji & $>60$ & 78.5 & 587.6 & 587.6 & 18.0 & 32.6 \\
\hline 2001 & 10 Aug & Rainstorm & 3 & 22.4 & 22.4 & 22.4 & 1.0 & 22.4 \\
\hline 2001 & 17 Sep & Typhoon Nari & 4 & 35.7 & 252.5 & 252.5 & 23.0 & 11.0 \\
\hline 2002 & 31 May & Rainstorm & 4 & 14.4 & 53.0 & 53.0 & 7.0 & 7.6 \\
\hline 2002 & 3-4 Jul & Rainstorm & 2 & 13.3 & 117.9 & 164.9 & 19.0 & 8.7 \\
\hline 2002 & 12 Aug & Rainstorm & 1 & 17.1 & 26.5 & 26.5 & 3.0 & 8.8 \\
\hline 2004 & 2-3 Jul & Typhoon Mindulle & $>10$ & 54.0 & 681.4 & 864.1 & 38.0 & 22.7 \\
\hline 2004 & 23-25 Aug & Typhoon Aere & 2 & 35.0 & 385.4 & 675.0 & 47.0 & 14.4 \\
\hline 2005 & 4-5 Aug & Typhoon Matsa & 1 & 42.3 & 411.9 & 471.9 & 34.0 & 13.9 \\
\hline 2005 & 31 Aug-1 Sep & Rainstorm & 1 & 44.3 & 495.0 & 517.3 & 27.0 & 19.2 \\
\hline 2006 & 8-11 Jun & Rainstorm & $>5$ & 77.5 & 682.8 & 1227.6 & 78.0 & 15.7 \\
\hline 2006 & $13-15 \mathrm{Jul}$ & Typhoon Bilis & 2 & 29.9 & 371.7 & 664.9 & 56.0 & 11.9 \\
\hline 2007 & 17-20 Aug & Typhoon Sepat & 1 & 31.6 & 328.4 & 621.4 & 66.0 & 9.4 \\
\hline 2007 & 6-7 Oct & Typhoon Krosa & 1 & 54.3 & 669.4 & 782.2 & 35.0 & 22.3 \\
\hline 2008 & $17-18 \mathrm{Jul}$ & Typhoon Kalmaegi & 3 & 67.2 & 515.7 & 515.7 & 18.0 & 28.7 \\
\hline 2008 & 12-15 Sep & Typhoon Sinlaku & 2 & 35.0 & 612.4 & 1164.2 & 66.0 & 17.6 \\
\hline 2009 & 6-11 Aug & Typhoon Morakot & $>30$ & 85.5 & 1192.6 & 2471.8 & 110.0 & 22.5 \\
\hline
\end{tabular}

Note: $N=$ total number of individual debris flow triggered by each rainfall event in the Chenyulan stream watershed; $I_{\mathrm{m}}=$ maximum hourly rainfall in each rainfall event; $R_{\mathrm{d}}=$ maximum 24-h rainfall amount in each rainfall event; $R=$ total rainfall calculated from the start of rainfall to the end of rainfall; $T=$ rainfall duration corresponding to estimate total rainfall $R ; I=$ mean rainfall intensity, $I=R / T$.

from the meteorological station $i$ to the centroid of the considered watershed. In the study, the weighting factors $w_{1}, w_{2}$, and $w_{3}$ are $0.099,0.387$, and 0.514 , respectively.

The rainfall characteristics estimated by the reciprocaldistance-squared method may not actually reflect the rainfall characteristics at specific locations when local rainfall varied significantly owing to abrupt changes in elevation, but it is a simple method to directly compute the regional average rainfall characteristics for a watershed. The regional average rainfall in the Chenyulan stream watershed was computed by Eq. (1) on the basis of the hourly rainfall records from the three meteorological stations. In the Chenyulan stream watershed, rainstorms, thundershowers, and typhoons occur frequently during the rainy season, from May to October. Most debris flows, in particular those associated with typhoons, occur in the rainy season. Typhoons generally bring heavy rainfall and result in significant debris flows in the watershed.

The five-year-moving-average variations in the annual rainfall and the rainy-season rainfall at the three meteorological stations and the corresponding regional average rainfall in the Chenyulan stream watershed are presented in Fig. 2a and $b$. The average annual rainfall in the watershed is between $2500 \mathrm{~mm}$ and $4500 \mathrm{~mm}$, with an average value of 


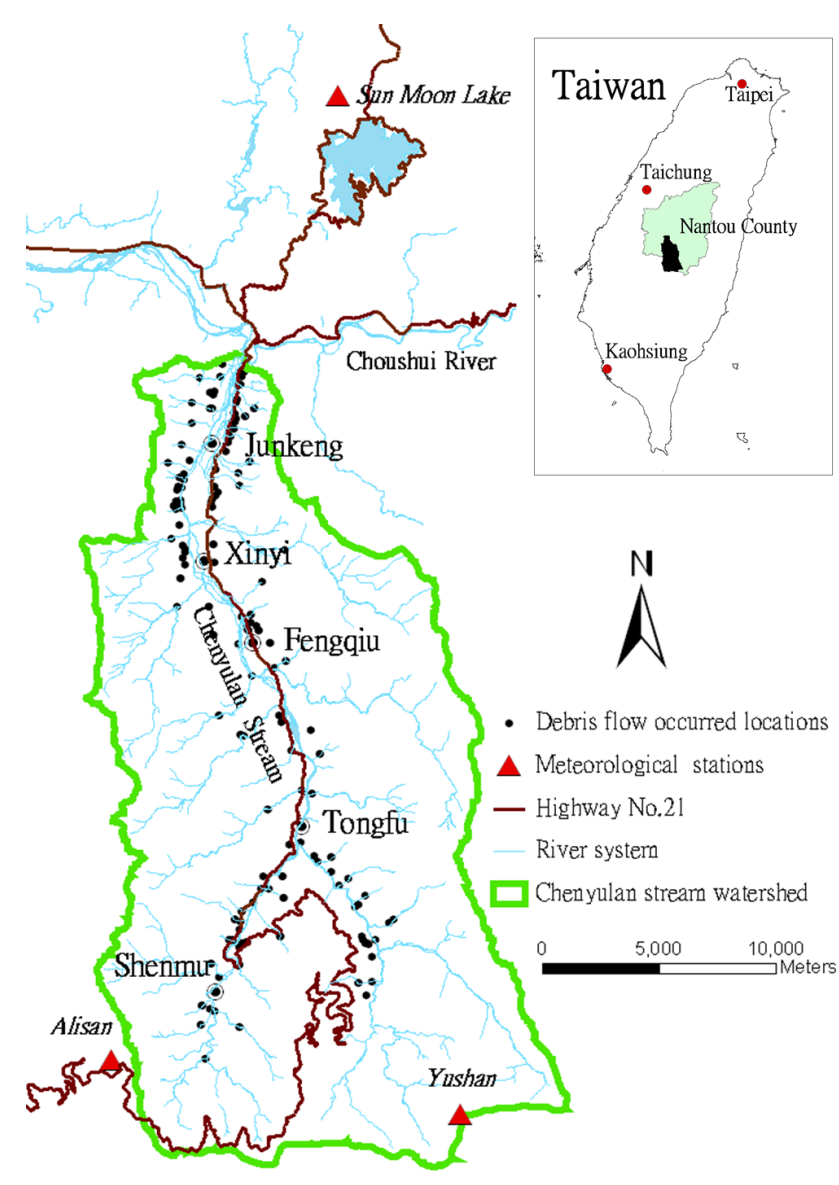

Fig. 1. Locations of debris flows and meteorological stations in Chenyulan stream watershed

approximately $3500 \mathrm{~mm}$. The average annual rainfall in the rainy season, from May to October, ranges between $2100 \mathrm{~mm}$ and $4000 \mathrm{~mm}$, with an average value of about $2800 \mathrm{~mm}$. This shows that the accumulated rainfall during the rainy season is about $80 \%$ of the annual total. Figure $2 \mathrm{a}$ and $\mathrm{b}$ also shows that the annual rainfall and the rainy-season rainfall decreased slightly between 1975 and 2003, but increased sharply after 2003. The variation in the regional average rainfall shows a trend similar to the rainfall measured at the three rainfall stations. The results suggest that the regional average rainfall computed by Eq. (1) can reasonably represent the variation trend of the regional rainfall characteristics in the entire Chenyulan stream watershed; hence, the reciprocal-distance-squared method (Eq. 1) was used to analyze the recent changes in the regional average rainfalls related to debris-flow occurrences in the watershed.

Table 1 lists the regional average rainfalls that triggered debris flows in the Chenyulan stream watershed between 1985 and 2009. The rainfall data for a rainfall event that triggered debris flows include the maximum hourly rainfall $I_{\mathrm{m}}$, the maximum 24-h rainfall $R_{\mathrm{d}}$, the accumulated rainfall $R$ from the initiation of rainfall to the end of rainfall,

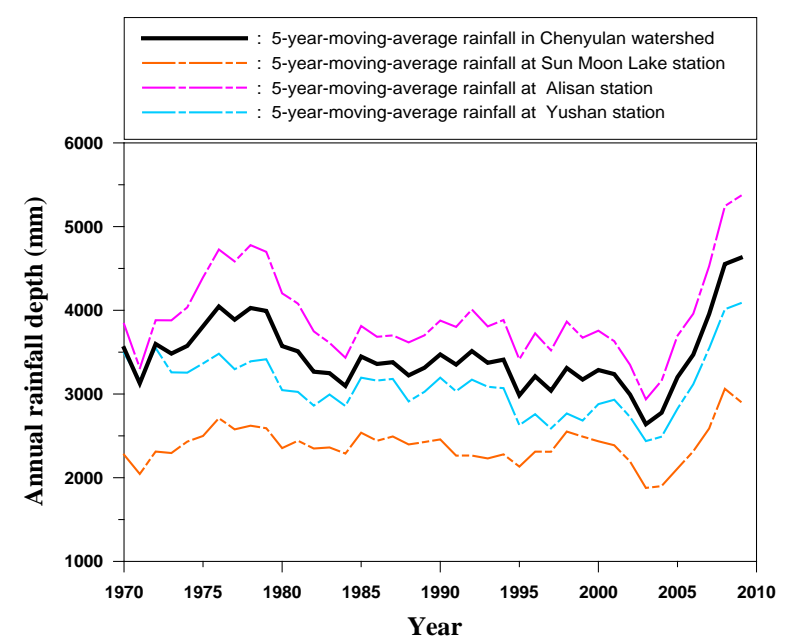

(a) Variation in 5-year-moving average annual rainfall

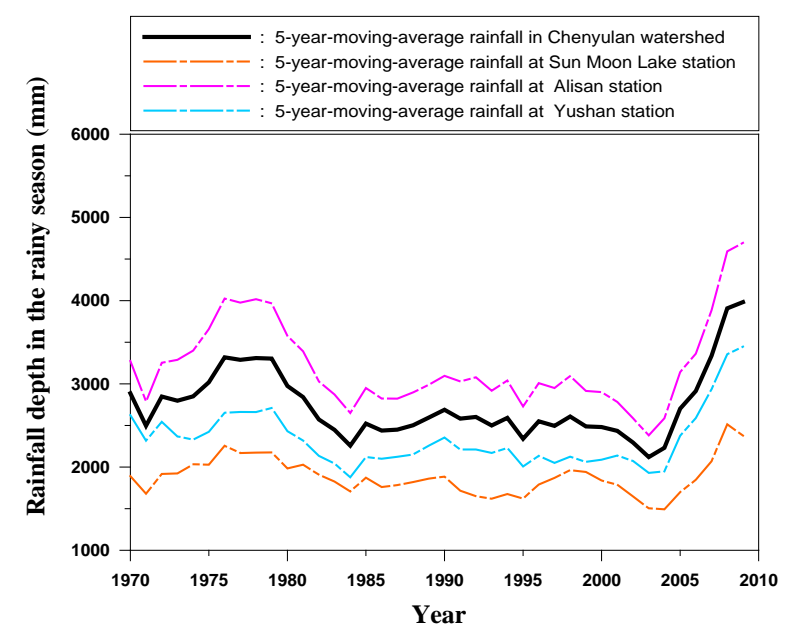

(b) Variation in 5-year-moving average rainfall in annual rainy season

Fig. 2. Variations in 5-yr-moving average annual rainfall and rainyseason rainfall (May to October) at three local rainfall stations and the regional average rainfall for the whole Chenyulan stream watershed.

the rainfall duration $T(\mathrm{~h})$ from rainfall initiation to the end of rainfall, and the average rainfall intensity $I\left(\mathrm{~mm} \mathrm{~h}^{-1}\right)$ defined as $I=R / T$. The number of debris flow events $N$ is defined as the total number of individual debris flow triggered by each rainfall event in the Chenyulan stream watershed; the value of $N$ triggered by a rainstorm or typhoon event is also mentioned in Table 1. Prior to 1996, the number of debris flows was collected from papers (Yu and Chen, 1987; Chiang and Lin, 1991; Chang et al., 2001) without covering the whole watershed due to lack of data from field investigations. After 1996, the number of debris flows was collected from related documents and papers (Lin and Jeng, 2000; Cheng et al., 2005; Jan and Chen, 2005; Chen et al., 2009; Chen, 2011) and identified through interpretations of aerial photographs and field investigations in the whole watershed. 


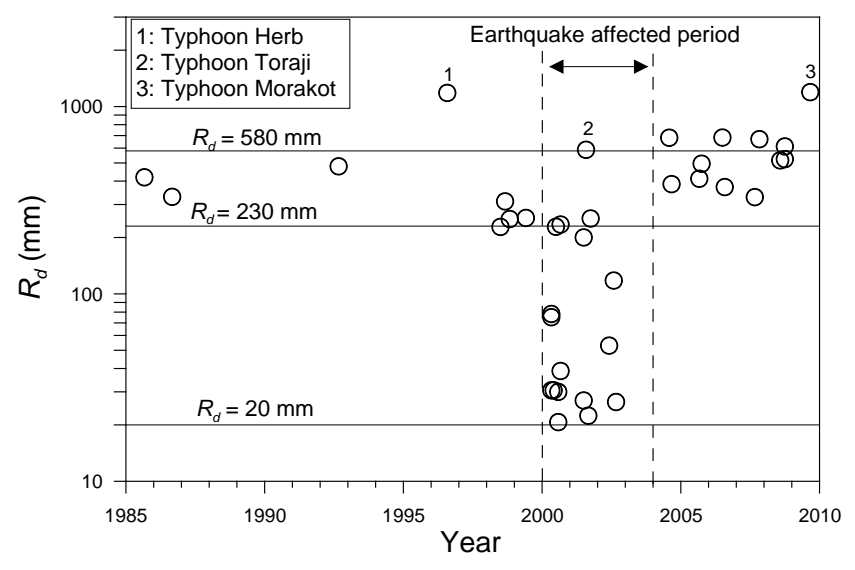

Fig. 3. Maximum 24-h rainfall $R_{\mathrm{d}}(\mathrm{mm})$ during any rainfall event that triggered debris flows over past decades.

\section{The rainfall conditions of debris-flow occurrences}

Previous researchers have used many rainfall parameters, including $I_{\mathrm{m}}, R_{\mathrm{d}}, R, I$, and $T$, to study the occurrence of debris flows. The choice of rainfall parameters adopted may vary according to different objectives. For example, empirical relationships between average rainfall intensity and rainfall duration have been proposed and generally used to issue debris-flow warnings (Caine, 1980; Keefer et al., 1987; Chen et al., 2005; Chen, 2011). $I_{\mathrm{m}}$ and $R_{\mathrm{d}}$ have been used to determine the rainfall conditions for debris-flow occurrence in an extreme rainfall event (Lin and Jeng, 2000; Cheng et al., 2005). The daily rainfall or 3-day rainfall in a rainfall event has been used to analyze the influence of climatic or rainfall change on debris-flow activity (Rebetez et al., 1997; Zhuang et al., 2011).

Debris-flow occurrence is strongly related to extreme rainfall events (Rebetez et al., 1997; Zhuang et al., 2011). $R_{\mathrm{d}}$ is one of several simple indices representing extreme rainfall characteristics. Furthermore, it was found that debris flows initiated in the Chenyulan stream watershed were closely related to $R_{\mathrm{d}}$. All debris flows triggered by a rainfall event in the watershed was within the period of maximum 24-h rainfall. Thus, the present study used $R_{\mathrm{d}}$ to analyze recent changes in the relationship between the number of specified rainfall events and debris-flow occurrence. Figure 3 shows the values of $R_{\mathrm{d}}$ for rainfall events that triggered debris flows during the data series (1985-2009). It is clear that the lowest values of $R_{\mathrm{d}}$ that triggered debris flows were recorded during the period 2000 to 2004. Therefore, it is believed that the influence of the 1999 Chi-Chi earthquake on debris flow initiation lasted approximately $5 \mathrm{yr}$ (Chen, 2011). Three critical rainfall conditions for debris-flow occurrence were imposed on Fig. 3. They are (1) condition A: $R_{\mathrm{d}}=20 \mathrm{~mm}$, which is the lower boundary of the values of $R_{\mathrm{d}}$ in Fig. 3 for the period 1999-2004; (2) condition $\mathrm{B}: R_{\mathrm{d}}=230 \mathrm{~mm}$, which is the

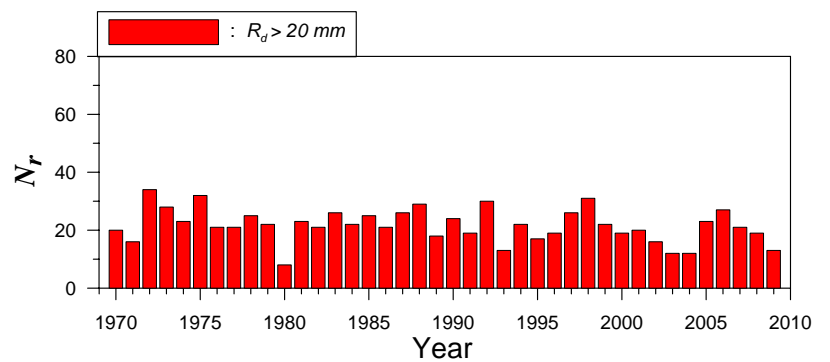

(a) Annual number $\left(N_{r}\right)$ of rainfall events with maximum 24-h rainfall greater than $20 \mathrm{~mm}$.

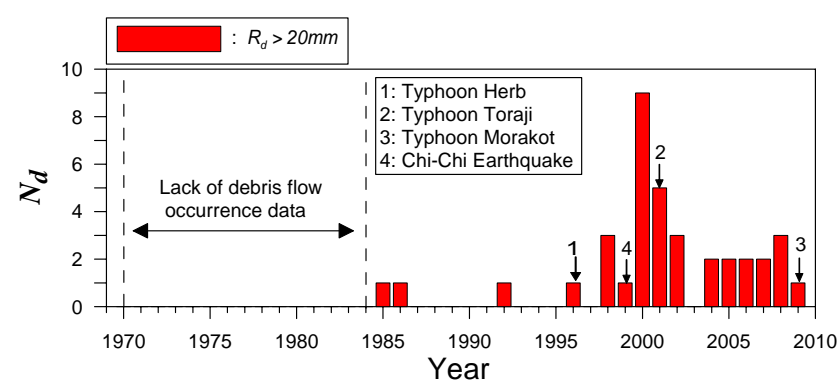

(b) Annual number ( $N_{d}$ ) of rainfall events with maximum 24-h rainfall greater than $20 \mathrm{~mm}$ that triggered debris flows.

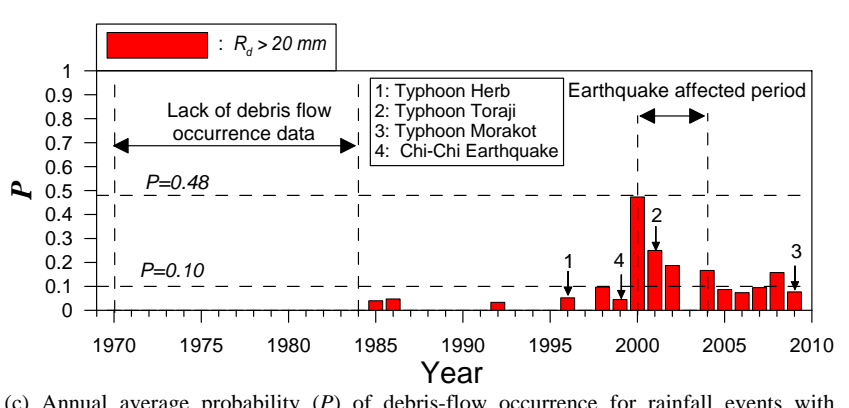

(c) Annual average probability $(P)$ of debris-flow occurrence for rainfall events with maximum 24-h rainfall greater than $20 \mathrm{~mm}$.

Fig. 4. Number of annual rainfall events, number of annual rainfall events that triggered debris flow, and annual average probability of debris-flow occurrence for rainfall events with maximum 24-h rainfall greater than $20 \mathrm{~mm}$.

lower boundary of the values of $R_{\mathrm{d}}$ in Fig. 3 for the period 1985 to 1999, prior to the Chi-Chi earthquake; and (3) condition C: $R_{\mathrm{d}}=580 \mathrm{~mm}$, which is the approximate $R_{\mathrm{d}}$ threshold, above which numerous debris flows $(N>30)$ were initiated during rainfall events, including Typhoon Herb in 1996, Typhoon Toraji in 2001, and Typhoon Morakot in 2009. The variation trends in the number of rainfall events, the number of rainfall events triggering debris flows, and the probability of debris-flows occurrence for the three rainfall conditions $(\mathrm{A}-\mathrm{C})$ were analyzed and the results are discussed in the following section.

\subsection{Condition A: rainfall events with $R_{d}>20 \mathrm{~mm}$}

Figure $4 \mathrm{a}$ shows that the annual number $\left(N_{\mathrm{r}}\right)$ of rainfall events having $R_{\mathrm{d}}>20 \mathrm{~mm}$ in the Chenyulan stream 


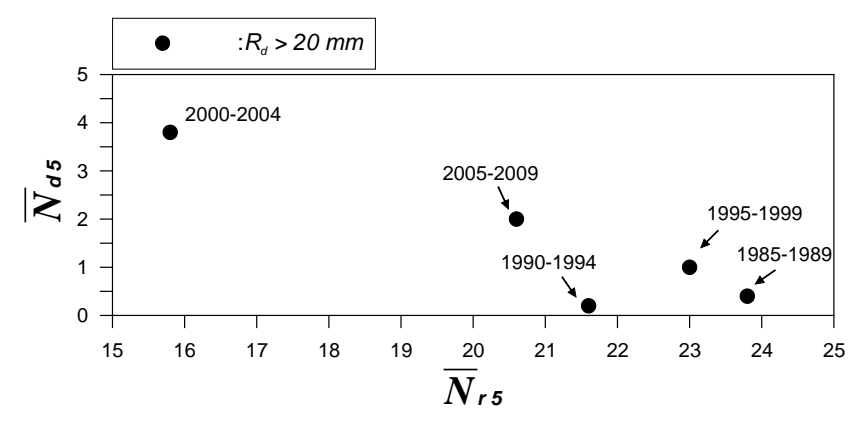

Fig. 5. Relationship between five-year-average number of rainfall events that triggered debris flows $\bar{N}_{\mathrm{d} 5}$ and five-year-average number of rainfall events $\bar{N}_{\text {r5 }}$ with maximum 24-h rainfall greater than $20 \mathrm{~mm}$.

watershed (1970 to 2009) ranges from 8 to 34 (average 21.7), but without a clearly increasing or decreasing trend. Figure $4 \mathrm{~b}$ shows that the annual number $\left(N_{\mathrm{d}}\right)$ of rainfall events that triggered debris flows is between 0 and 9 , with larger numbers occurring between 2000 and 2002 owing to the influence of the Chi-Chi earthquake, which provided the loose sediment required for debris-flow occurrence (Lin et al., 2003; Chen, 2011). Figure $4 \mathrm{c}$ shows the annual average probability $P\left(=N_{\mathrm{d}} / N_{\mathrm{r}}\right)$ of debris-flow occurrence for rainfall events having $R_{\mathrm{d}}>20 \mathrm{~mm}$ is less than $48 \%$; there was an abrupt increase after Typhoon Herb in 1996, and the peak value was observed in the year 2000 immediately after the Chi-Chi earthquake since Typhoon Herb and the ChiChi earthquake resulted in large amounts of loose sediment in catchments (Lin and Jeng, 2000; Lin et al., 2003). After 2000, both $N_{\mathrm{d}}$ and $P$ decreased slowly because the loose sediment became more consolidated and re-orientated with time, less soil and rock was deposited in streams after each storm, and the shear strength of soil gradually recovered (Fan et al., 2003; Chen, 2011). In response, the amount of rainfall required to trigger a debris flow gradually increased and the values of $N_{\mathrm{d}}$ and $P$ for the same rainfall condition $\left(R_{\mathrm{d}}>20 \mathrm{~mm}\right)$ decreased with time. Figure $4 \mathrm{c}$ shows that the value of $P$ before the Chi-Chi earthquake was generally less than $10 \%$, which is the same as that after 2004. This implies that the probability of debris-flow occurrence after 2004 reverted to the pre-earthquake condition. The influence of the Chi-Chi earthquake on debris flow initiation was substantial during the period 2000-2004. This finding is consistent with a previous study by Chen (2011).

Figures 5 and 6 show the relationship between the fiveyear-average for rainfall events triggering debris flows $\bar{N}_{\mathrm{d} 5}$ and the five-year-average number of rainfall events $\bar{N}_{\text {r } 5}$; also shown is the relationship between the probability of debrisflows occurrences in a five-year period $\bar{P}_{5}\left(=\bar{N}_{\mathrm{d} 5} / \bar{N}_{\mathrm{r} 5}\right)$ and $\bar{N}_{\mathrm{r} 5}$ for the condition-A rainfall events. The values of $\bar{N}_{\mathrm{d} 5}$ and $\bar{P}_{5}$ during the Chi-Chi earthquake-affected period (20002004) were significantly greater than those during other

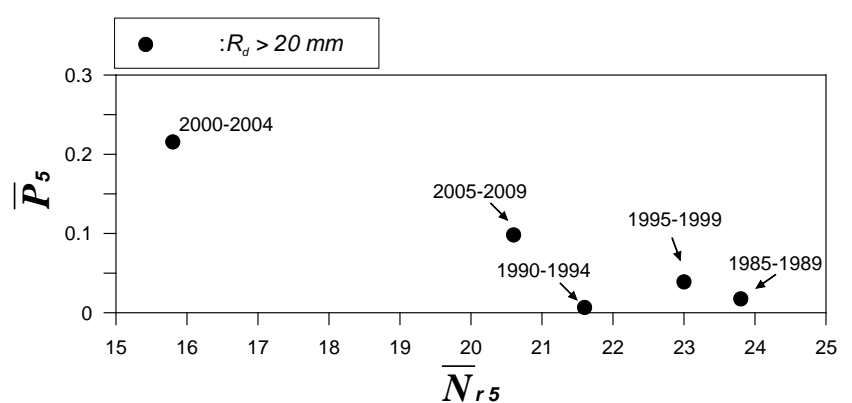

Fig. 6. Relationship between the five-year-average probability of debris-flow occurrence $\bar{P}_{5}$ and the five-year-average number of rainfall events $\bar{N}_{\mathrm{r} 5}$ with maximum 24-h rainfall greater than $20 \mathrm{~mm}$.

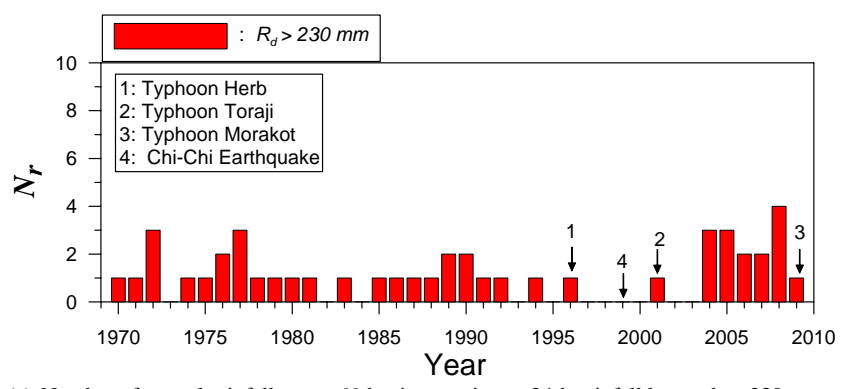

(a) Number of annual rainfall events $N_{r}$ having maximum 24-h rainfall larger than $230 \mathrm{~mm}$.

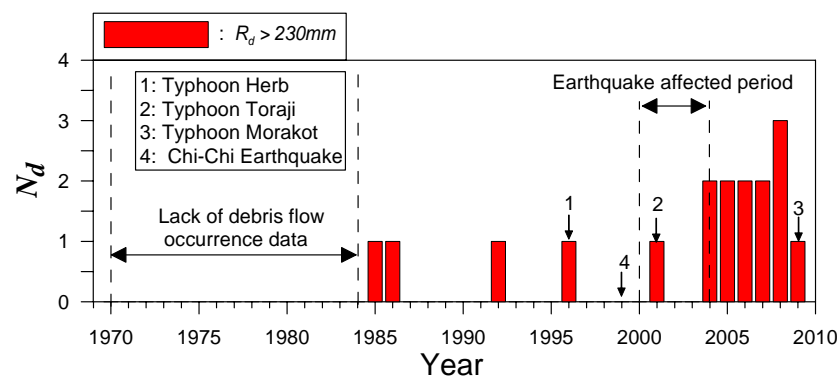

(b) Number of annual rainfall events $N_{d}$ that triggered debris flows for rainfall events having maximum 24-h rainfall larger than $230 \mathrm{~mm}$

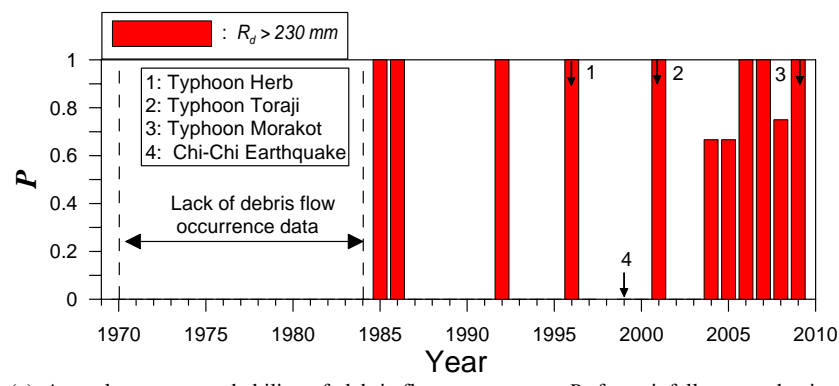

(c) Annual average probability of debris-flow occurrence $P$ for rainfall events having maximum 24-h rainfall larger than $230 \mathrm{~mm}$.

Fig. 7. Number of annual rainfall events $N_{\mathrm{r}}$, number of annual rainfall events $N_{\mathrm{d}}$ that triggered debris flows, and annual average probability of debris-flow occurrence $P$ for rainfall events having maximum 24-h rainfall larger than $230 \mathrm{~mm}$. 


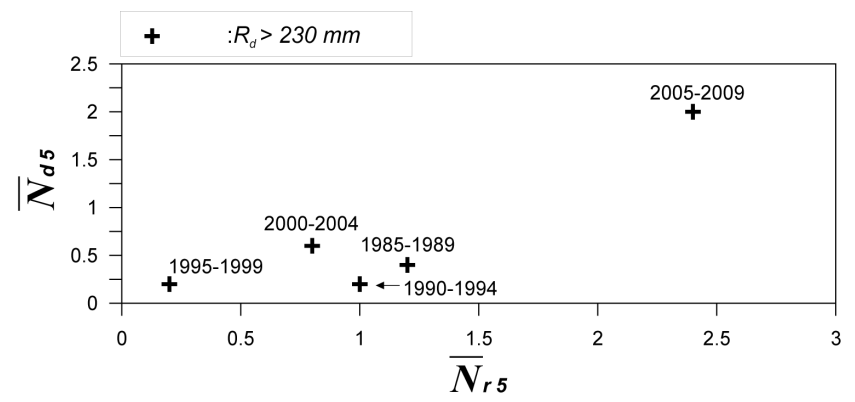

Fig. 8. Relationship between the five-year-average number of rainfall events that ever triggered debris flows $\bar{N}_{\mathrm{d} 5}$ and the five-yearaverage number of rainfall events $\bar{N}_{\mathrm{r} 5}$ for rainfall events having maximum 24-h rainfall larger than $230 \mathrm{~mm}$.

periods. The value of $\bar{N}_{\mathrm{d} 5}$ in the earthquake-affected period is 3.8 times that during the five-year period pre-earthquake (1995-1999); the probability of debris-flow occurrences $\left(\bar{P}_{5}\right)$ in the earthquake-affected period is 5.5 times that during the five years pre-earthquake; in particular, the $\bar{N}_{\mathrm{r} 5}(2000-$ 2004) is less than $\bar{N}_{\text {r5 }}$ (1995-1999). The condition-A rainfall events $\left(R_{\mathrm{d}}>20 \mathrm{~mm}\right)$ during the earthquake-affected period strongly responded to the increases in $\bar{N}_{\mathrm{d} 5}$ and $\bar{P}_{5}$, especially within the period (2000-2004) of the lowest number of rainfall events.

\subsection{Condition B: Rainfall events with $R_{d}>230 \mathrm{~mm}$}

Before the Chi-Chi earthquake, debris flows generally occurred when $R_{\mathrm{d}}>230 \mathrm{~mm}$. Figure $7 \mathrm{a}$ and b shows that the number of rainfall events with $R_{\mathrm{d}}>230 \mathrm{~mm}$ that have high values of $N_{\mathrm{r}}>2$ was concentrated in the period of 2004 and 2008 , and the number of rainfall events that triggered debris flows was highest between 2004 and 2008. However, the highest value of $N_{\mathrm{d}}$ in the period 2004-2008 may not correspond to the highest probability of debris-flows occurrence since the probability of debris-flow occurrence was the lowest for the rainfall events in 2004 and 2005 (Fig. 7c). This result may be attributed to the fact that during the period 2004-2005, the large amount of loose sediments attributed to the 1999 Chi-Chi earthquake decreased after Typhoon Toraji (Lin et al., 2003) and after the earthquake-affected period (Chen, 2011); furthermore, this result may be also attributed to insufficient loose sediment generated by each rainfall event in 2004 and 2005. Because a large amount of loose sediment is required for debris-flows occurrence, the probability of debris-flow occurrence decreased. Beginning in 2006, the probability of debris-flows occurrence increased; this may be due to a large amount of loose sediment accumulated or generated in the Chenyulan stream watershed. The annual rainfall event with $R_{\mathrm{d}}>580 \mathrm{~mm}$ that ever triggered numerous debris-flows occurred annually after 2006.

Figure 8 shows the relationship between the five-yearaverage number $\left(\bar{N}_{\mathrm{d} 5}\right)$ of rainfall events of $R_{\mathrm{d}}>230 \mathrm{~mm}$

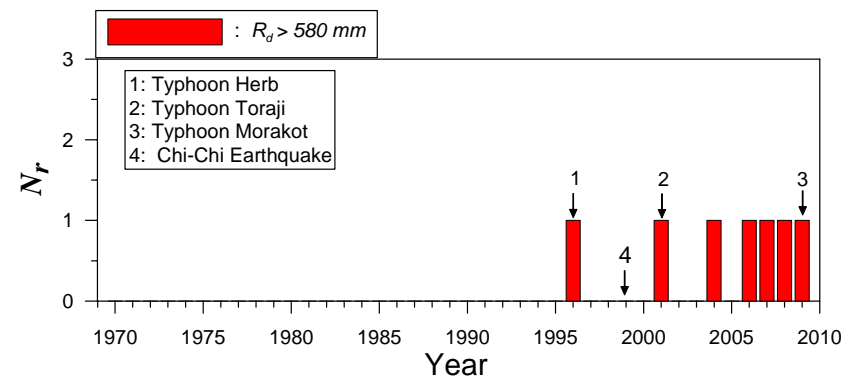

(a) Number of annual rainfall events $N_{r}$ having maximum 24-h rainfall larger than $580 \mathrm{~mm}$.

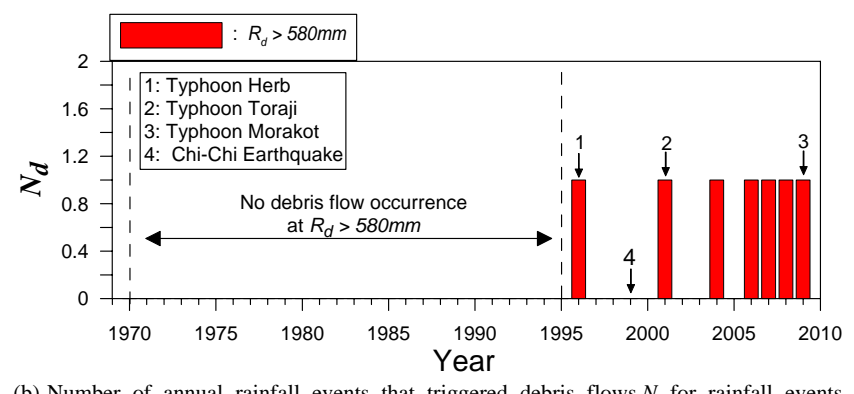

(b) Number of annual rainfall events that triggered debris flows $N_{d}$ for rainfall events having maximum 24-h rainfall larger than $580 \mathrm{~mm}$.

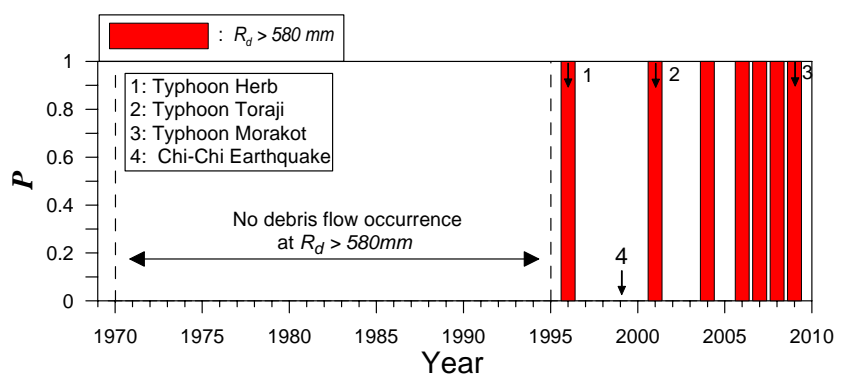

(c) Annual average probability of debris-flow occurrence $P$ for rainfall events having maximum 24-h rainfall larger than $580 \mathrm{~mm}$.

Fig. 9. Number of annual rainfall events $N_{\mathrm{r}}$, number of rainfall events $N_{\mathrm{d}}$ that triggered debris flows, and annual average probability of debris-flow occurrence $P$ for rainfall events having maximum 24-h rainfall larger than $580 \mathrm{~mm}$.

that triggered debris flows and the five-year-average number $\left(\bar{N}_{\mathrm{r} 5}\right)$ of rainfall events of $R_{\mathrm{d}}>230 \mathrm{~mm}$. The five-yearaverage of rainfall events triggering debris flows $\left(\bar{N}_{\mathrm{d} 5}\right)$ increased with the increase in the five-year-average number of rainfall events.

\subsection{Condition C: rainfall events with $R_{d}>580 \mathrm{~mm}$}

The number $\left(N_{\mathrm{r}}\right)$ of rainfall events of $R_{\mathrm{d}}>580 \mathrm{~mm}$ during 1970-2009 is shown in Fig. 9a. There are seven rainfall events with $R_{\mathrm{d}}>580 \mathrm{~mm}$. This magnitude of rainfall event first occurred in 1996, followed by 2001 ( $5 \mathrm{yr}$ later), 2004 (3 yr later), 2006 ( 2 yr later), and then occurred almost annually. All rainfall events, including six typhoons and one rainstorm, of $R_{\mathrm{d}}>580 \mathrm{~mm}$ resulted in debris flows and these rainfall events resulted in a $100 \%$ probability of debris-flows 


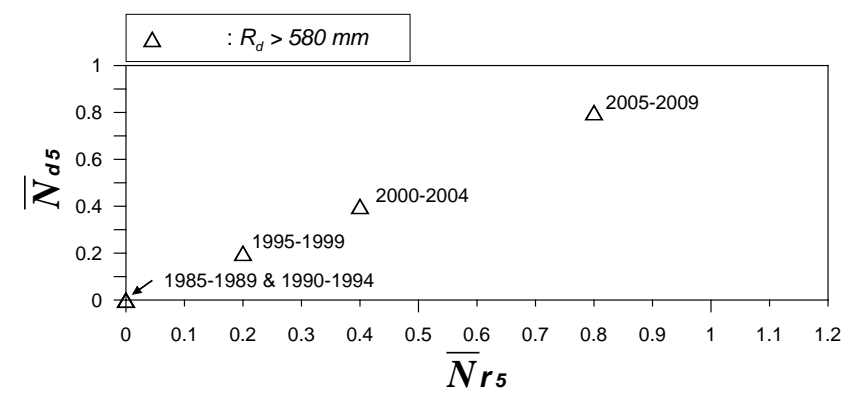

Fig. 10. Relationship between the five-year-average number of rainfall events that triggered debris flows $\bar{N}_{\mathrm{d} 5}$ and the five-year-average number of rainfall events $\bar{N}_{\mathrm{r} 5}$ for rainfall events having maximum 24-h rainfall larger than $580 \mathrm{~mm}$.

occurrence (Fig. 9b and c). The three typhoons, Herb, Toraji and Morakot, caused many debris flows $(N>30)$. In particular, Typhoon Toraji (2001) resulted in more than 60 debrisflow events in the Chenyulan stream watershed, despite having lower rainfall $\left(R_{\mathrm{d}}=588 \mathrm{~mm}\right)$ than the other six rainfall events with $R_{\mathrm{d}}>580 \mathrm{~mm}$. The high number of debris-flows $N$ occurring during Typhoon Toraji is inferred to be related to the occurrence of this event during the Chi-Chi earthquake affected period (2000-2004) when abundant loose sediment derived from the earthquake was present in the watershed.

Figure 10 shows the five-year average number $\left(\bar{N}_{\mathrm{d} 5}\right)$ for rainfall events triggering debris flows against the five-year average number $\left(\bar{N}_{\mathrm{r} 5}\right)$ for rainfall events. As all rainfall events with $R_{\mathrm{d}}>580 \mathrm{~mm}$ triggered debris flows, the number of such rainfall events triggering debris flows $\bar{N}_{\mathrm{d} 5}$ was perfectly correlated with the five-year average for the number of rainfall events $\bar{N}_{\mathrm{r} 5}$ for the condition-C rainfall events. The five-year average number of rainfall events triggering debris flows $\left(\bar{N}_{\mathrm{d} 5}\right)$ increased with the higher five-year average number of rainfall events. As seen in Fig. 10, both $\bar{N}_{\mathrm{d} 5}$ and $\bar{N}_{\mathrm{r} 5}$ also showed increasing trends after 1990.

\section{Variations in rainfall events triggering debris flows and the probability of debris-flow occurrence in each decade}

\subsection{Variations in the number of rainfall events}

Figure 11 shows variations in the ten-year average for rainfall events $\bar{N}_{\text {r10 }}$, with $R_{\mathrm{d}}$ larger than various rainfall thresholds $R_{\mathrm{dc}}$ for two separate decades 1990-1999 and 20002009. The number of rainfall events for $R_{\mathrm{d}}>100 \mathrm{~mm}$ at various values of $R_{\mathrm{dc}}$ during the period 1990-1999 is less than that in 2000-2009. For larger $R_{\mathrm{dc}}$, the value of $\bar{N}_{\mathrm{r} 10}$ in 2000-2009 is significantly larger than that in 1990-1999. This implies that there were more extreme rainfall events in the recent decade (2000-2009). The value of $\bar{N}_{\text {r10 }}$ for the condition-A rainfall event $\left(R_{\mathrm{d}}>20 \mathrm{~mm}\right)$ during 2000-2009 was around $10 \%$ less than that in 1990-1999. The values

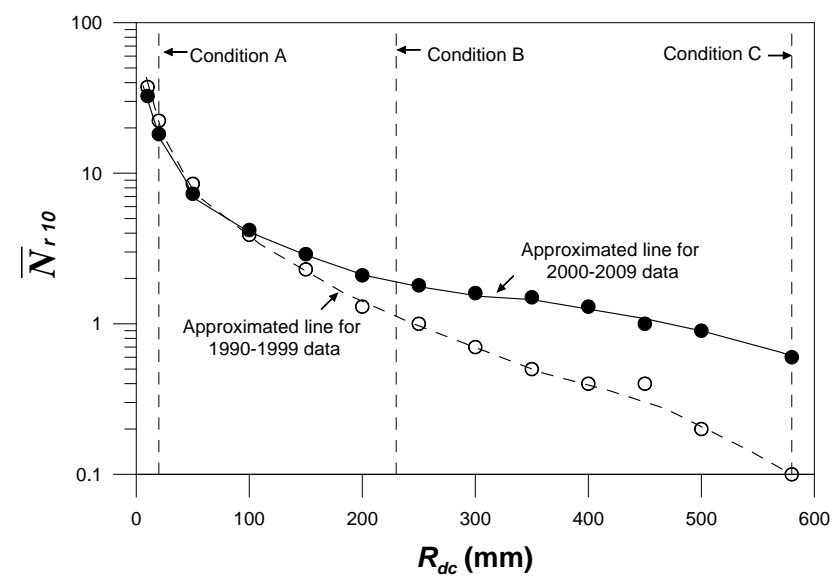

Fig. 11. Variations in ten-year average number of rainfall events $\bar{N}_{\mathrm{r} 10}$ with $R_{\mathrm{d}}$ greater than rainfall thresholds $R_{\mathrm{dc}}$, such as $R_{\mathrm{dc}}=20$, $100, .$. , and $580 \mathrm{~mm}$, during the periods $1990-1999$ and 2000-2009.

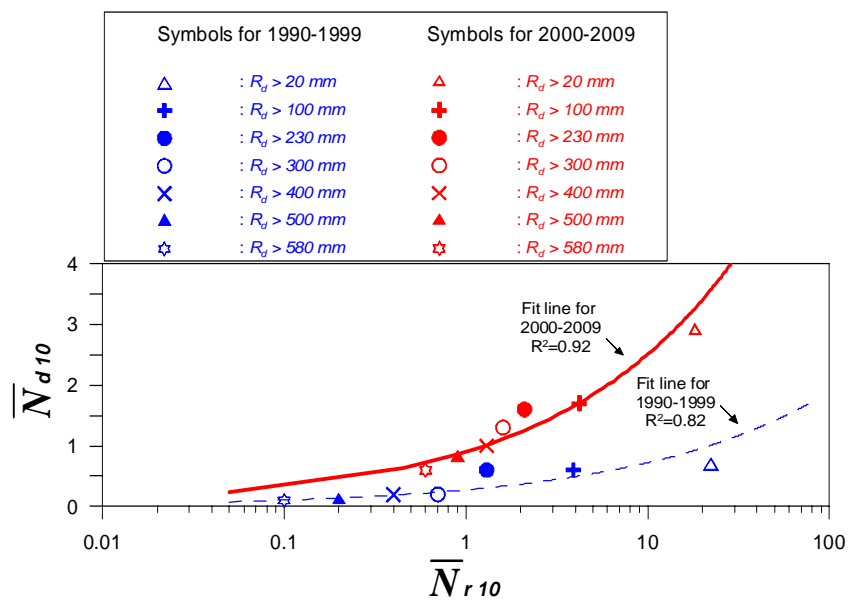

Fig. 12. Relationship between the ten-year-average number of rainfall events that triggered debris flows $\bar{N}_{\mathrm{d} 10}$ and the ten-year-average number of rainfall events $\bar{N}_{\text {r10 }}$ with $R_{\mathrm{d}}$ greater than various rainfall thresholds $R_{\mathrm{dc}}$, such as $R_{\mathrm{dc}}=20,100, .$. , and $580 \mathrm{~mm}$, during the periods 1990-1999 and 2000-2009.

of $\bar{N}_{\text {r10 }}$ for the rainfall events during 2000-2009 were 1.8 (condition $\mathrm{B}$ ) and 6 (condition $\mathrm{C}$ ) times the corresponding values in 1990-1999. Owing to the variation in the number of rainfall events in the past two decades, the influence of the variation in the number of rainfall events relative to debris flows and the probability of debris-flow occurrence were analyzed in the following sections.

\subsection{The relationship between the number of rainfall events triggering debris flows and the number of rainfall events}

Figure 12 shows the relationship between the ten-year average number of rainfall events triggering debris flows $\bar{N}_{\mathrm{d} 10}$ and the ten-year-average number of rainfall events $\bar{N}_{\text {r10 }}$ at 


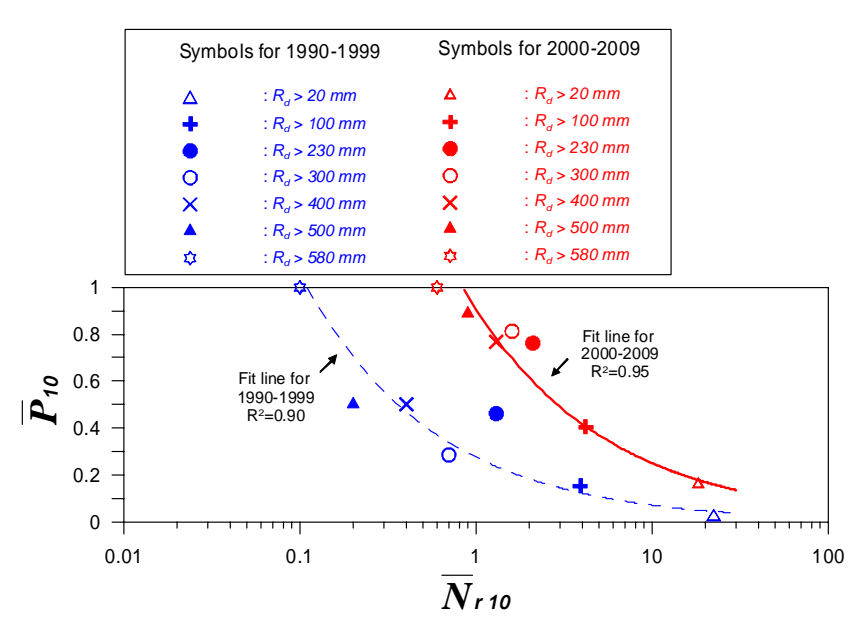

Fig. 13. Relationship between the ten-year-average probability of debris-flow occurrence $\bar{P}_{10}$ and the ten-year-average number of rainfall events $\bar{N}_{\text {r10 }}$ with $R_{\mathrm{d}}$ greater than various rainfall thresholds $R_{\mathrm{dc}}$, such as $R_{\mathrm{dc}}=20,100, .$. , and $580 \mathrm{~mm}$, during the periods 1990-1999 and 2000-2009.

various rainfall conditions of $R_{\mathrm{d}}>R_{\mathrm{dc}}$ for two periods: 1990-1999 and 2000-2009. The values of $\bar{N}_{\mathrm{d} 10}$ in both periods increase with decreasing rainfall thresholds $R_{\mathrm{dc}}$. For the period 1990-1999 and 2000-2009, larger rainfall thresholds $R_{\mathrm{dc}}$ are generally associated with lower $\bar{N}_{\mathrm{r} 10}$ and correspond to lower $\bar{N}_{\mathrm{d} 10}$. Figure 12 shows that the value of $\bar{N}_{\mathrm{d} 10}$ during 2000-2009 was greater than that during 1990-1999 at the same rainfall thresholds of $R_{\mathrm{dc}}$. As indicated by the solid circle symbols shown in Fig. 12, the number of rainfall events that triggered debris flows $\bar{N}_{\mathrm{d} 10}$ for the condition-B rainfall events $\left(R_{\mathrm{d}}>230 \mathrm{~mm}\right)$ during $2000-2009$ was around 3 times that in 1990-1999; for the condition-A $\left(R_{\mathrm{d}}>20 \mathrm{~mm}\right)$ and condition-C rainfall events $\left(R_{\mathrm{d}}>580 \mathrm{~mm}\right)$, the value of $\bar{N}_{\mathrm{d} 10}$ in 2000-2009 was around 5 times that in 19901999. The two fit lines in Fig. 12 show that the value of $\bar{N}_{\text {d10 }}$ during 2000-2009 (with the coefficient of determination, $R^{2}=0.92$ ) was around 3-4 times that during 1990$1999\left(R^{2}=0.82\right)$ at the same value of $\bar{N}_{\text {r10 }}$.

\subsection{The relationship between the probability of debris-flow occurrence and the number of rainfall events}

Figure 13 shows the relationship between the ten-yearaverage probability of debris-flow occurrences $\bar{P}_{10}$ and the ten-year-average number of rainfall events $\bar{N}_{\text {r10 }}$ for various excess-rainfall conditions in the two periods 1990-1999 and 2000-2009. The $\bar{P}_{10}$ value for each period shows a decreasing trend with an increase in $\bar{N}_{\text {r10 }}$. The value of $\bar{P}_{10}$ obtained from the 2000-2009 fit line is around 3 to 4 times that during 1990-1999 at the same $\bar{N}_{\text {r10 }}$.

The occurrence of debris flows depends on having a large amount of loose sediment generated in the watershed and an increasing number of extreme rainfall events. Significant hazardous events, such as Typhoons Herb in 1996, Toraji in 2001 and Morakot in 2009, and the Chi-Chi earthquake, triggered many landslides that produced sediment left on hillsides and in gully beds, which provided loose material for the initiation of debris flows. The loose sediment caused by typhoons and the earthquake was concentrated after 2000; this, combined with a large number of extreme rainfall events with $R_{\mathrm{d}}>580 \mathrm{~mm}$ (Fig. 11), resulted in numerous debris flows during the last decade (2000-2009). Consequently, both the annual average number of rainfall events triggering debris flows $\bar{N}_{\mathrm{d} 10}$ and the probability of debris-flow occurrences $\bar{P}_{10}$ were greater in the last decade than in 1990-1999.

\section{Conclusions}

The maximum 24-h rainfall $R_{\mathrm{d}}$ was used to analyze the trends in the number of rainfall events related to debrisflow occurrence in the Chenyulan stream watershed. Three rainfall conditions related to debris-flow occurrences presented in this study are (1) rainfall events of $R_{\mathrm{d}}>20 \mathrm{~mm}$, the lower boundary of $R_{\mathrm{d}}$ for rainfall events ever triggering debris flows during the period 2000 to 2004, the 1999 Chi-Chi earthquake affected period; (2) rainfall events of $R_{\mathrm{d}}>230 \mathrm{~mm}$, the lower boundary of $R_{\mathrm{d}}$ for rainfall events ever triggering debris flows during the period 1985 to 1999 , prior to the 1999 Chi-Chi earthquake; and (3) rainfall events of $R_{\mathrm{d}}>580 \mathrm{~mm}$, the lower boundary for extreme rainfall triggering numerous debris flows.

The Chi-Chi earthquake significantly reduced the amount of rainfall required to trigger a debris flow. The rainfall events associated with debris-flow occurrences resulting from the Chi-Chi earthquake mainly occurred in the period 2000-2004, the five years after the earthquake, and these debris flows were triggered by rainfall events with $R_{\mathrm{d}}>20 \mathrm{~mm}$. For $R_{\mathrm{d}}>20 \mathrm{~mm}$, the average number of rainfall events triggering debris flows and the average probability of debris flows within a five-year period, namely $\bar{N}_{\mathrm{d} 5}$ and $\bar{P}_{5}$, respectively, during the Chi-Chi earthquake-affected period (20002004) were greater than those during other periods at the same $\bar{N}_{\text {r5 }}$ (the average number of rainfall events within a five-year period). The average number of rainfall events triggering debris flows (the value of $\bar{N}_{\mathrm{d} 5}$ for $R_{\mathrm{d}}>20 \mathrm{~mm}$ ) during the earthquake-affected period was 3.8 times that during the five-year pre-earthquake period (1995-1999); the average probability of debris-flow occurrences $\left(\bar{P}_{5}\right)$ during the earthquake-affected period was 5.5 times that during the fiveyear pre-earthquake period. For $R_{\mathrm{d}}>20 \mathrm{~mm}$ events, the influence of $\bar{N}_{\mathrm{r} 5}$ on the values of $\bar{N}_{\mathrm{d} 5}$ was not significant. For $R_{\mathrm{d}}>230 \mathrm{~mm}$ and $R_{\mathrm{d}}>580 \mathrm{~mm}$ events, the values of $\bar{N}_{\mathrm{d} 5}$ tended to increase with an increase in $\bar{N}_{\text {r5 }}$ and all events with $R_{\mathrm{d}}>580 \mathrm{~mm}$ triggered debris flows.

The variations in the average number of rainfall events, the average number of rainfall events triggering debris flows, and 
the average probability of debris-flow occurrences in each decade, namely $\bar{N}_{\mathrm{r} 10}, \bar{N}_{\mathrm{d} 10}$, and $\bar{P}_{10}$, respectively, were analyzed. The value of $\bar{N}_{\mathrm{r} 10}$ for $R_{\mathrm{d}}>100 \mathrm{~mm}$ within the last decade (2000-2009) was higher than that during 1990-1999. The increase in $\bar{N}_{\text {r10 }}$ during the last decade resulted in an increasing frequency of rainfall events triggering debris flows. The average number of rainfall events triggering debris flows $\bar{N}_{\mathrm{d} 10}$ and the average probability of debris-flow occurrences $\bar{P}_{10}$ during the period $2000-2009$, increased 3 to 4 times relative to those of the period $1990-1999$ at the same $\bar{N}_{\text {r10 }}$. The increases in $\bar{N}_{\mathrm{d} 10}$ and $\bar{P}_{10}$ during 2000-2009 may be related to abundant loose sediment caused by typhoons and the ChiChi earthquake after 2000 and the increased number of extreme rainfall events $\left(R_{\mathrm{d}}>580 \mathrm{~mm}\right)$ that caused numerous debris flows during the last decade.

Acknowledgements. This work was partly supported by Grant Nos. NSC. 100-2625-M-006-005- and NSC. 100-2218-E-006-011from the National Science Council in Taiwan. The authors also appreciate David Keefer and two anonymous reviewers for their critical reviews and constructive comments.

Edited by: D. Keefer

Reviewed by: two anonymous referees

\section{References}

Ashraf, M., Loftis, J. C., and Hubbard, K. G.: Application of geostatistics to evaluate partial weather station networks, Agr. Forest Meteorol., 84, 255-271, 1997.

Bryant, E.: Climate, Process and change, Cambridge Publishing, Edinburgh, 209 pp., 1997.

Caine, N.: The rainfall intensity-duration control of shallow landslides and debris flows, Geograf. Ann., 62A, 23-27, 1980.

Chang, J. C., Shen, S. M., and Liu, Y. S.: A study on the occurrence of landslides and debris flows in four small catchments of the Chenyulan river, Geog. Res., 34, 63-83, 2001 (in Chinese).

Chen, C. Y., Chen, T. C., Yu, F. C., Yu, W. H., and Tseng, C. C.: Rainfall duration and debris-flow initiated studies for real-time monitoring, Environ. Geol., 47, 715-724, 2005.

Chen, J. C.: Variability of impact of earthquake on debris-flow triggering conditions: case study of Chen-Yu-Lan Watershed, Taiwan, Environ. Earth Sci., 64, 1787-1794, 2011.

Chen, J. C. and Jan, C. D.: Probabilistic analysis of landslide potential of an inclined uniform soil layer of infinite length - application, Environ. Geol., 54, 1175-1183, 2008.

Chen, J. C., Lin, C. W., and Wang, L. C.: Geomorphic characteristics of hillslope and channelized debris flows- A case study in the Shitou area of central Taiwan, J. Mt. Sci., 6, 266-273, 2009.

Chen, J. C., Huang, W. S., Jan, C. D., and Tsai, Y. F.: Rainfall conditions for the initiation of debris flows during Typhoon Morakot in the Chen-Yu-Lan watershed in central Taiwan, Proceedings of the 5th International Conference on Debris-Flow Hazards Mitigation, Padua, Italy, edited by: Genevois, R., Hamilton, D. L., and Prestininzi, A., 31-36, 2011.

Chen, W. S., Chen, Y. G., Chang, H. C., Lee, Y. H., and Lee, J. C.: Palaeoseismic study of the Chelungpu fault in the Wan-Fong area, West. Pacific Earth Sci., 1, 499-506, 2001.
Cheng, C. H.: A new approach for ranking fuzzy numbers by distance method, Fuzzy Sets Syst., 95, 307-317, 1998.

Cheng, J. D., Huang, Y. C., Wu, H. L., Yeh, J. L., and Chang, C. H.: Hydrometeorological and landuse attributes of debris flows and debris floods during Typhoon Toraji, July 29-30, 2001 in Central Taiwan, J. Hydrol., 306, 161-173, 2005.

Chow, V. T., Maidment, D. R., and Mays, L. W.: Applied hydrology, McGraw-Hill Inc., Singapore, 572 pp., 1988.

Dadson, S., Hovius, N., Chen, H., Dade, W. B., Lin, J. C., Hsu, M. L., Lin, C. W., Horng, M. J., Chen, T. C., Miliman, J., and Stark, C. P.: Earthquake-triggered increase in sediment delivery from an active mountain belt, Geol., 32, 373-376, 2004.

Fan, J. C., Liu, J. S., and Wu, M. F.: Determination of critical rainfall thresholds for debris -flow occurrence in central Taiwan and their revision after the 1999 Chi-Chi earthquake, Proceedings of the 3rd International Conference on Debris-Flow Hazards Mitigation, Davos, Switzerland, edited by: Rickenmann, D. and Chen, C. L., Rotterdam, Millpress, 103-114, 2003.

Huang, C. C., Lee, Y. H., Liu, H. P., Keefer, D. K., and Jibson, R. W.: Influence of surface-normal ground acceleration on the initiation of the Jih-Feng-Erh-Shan landslide during the 1999 ChiChi, Taiwan, earthquake, Bull. Seism. Soc. Am., 91, 953-958, 2001.

IPCC: Houghton, J. T., Meira Filho, L. G., Callander, B. A., Harris, N., Kattenberg, A., and Maskell, K. (Eds.), Climate change 1995: The science of climate change, Cambridge University Press, Cambridge, 572 pp., 1996.

Jan, C. D. and Chen, C. L.: Debris flow caused by Typhoon Herb in Taiwan, in: Debris-flow hazards and related phenomena, edited by: Jakob, M. and Hungr, O., Praxis, UK, 539-563, 2005.

Jakob, M. and Lambert, S.: Climate change effects on landslides along the south-west coast of British Columbia, Geomorphology, 107, 275-284, 2009.

Jomelli, V., Pech, V. P., Chochillon, C., and Brunstein, D.: Geomorphic variations of debris flows and recent climatic change in the French Alps, Climatic Change, 64, 77-102, 2004.

Katz, R. W. and Brown, B. G.: Extreme events in a changing climate: variability is more important than averages, Climate Change, 21, 289-302, 1992.

Keefer, D. K., Wilson, R. C., Mark, R. K., Brabb, E. E., Brown, W. M., Ellen, S. D., Harp, E. L., and Wieczorek, C. F.: Real-time landslide warning during heavy rainfall, Science, 238, 921-925, 1987.

Lin, C. W., Shieh, C. L., Yuan, B. D., Shieh, Y. C., Liu, S. H., and Lee, S. Y.: Impact of Chi-Chi earthquake on the occurrence of landslides and debris flows: Example from the Chenyulan River watershed, Nantou, Taiwan, Eng. Geol., 71, 49-61, 2003.

Lin, M. L. and Jeng, F. S.: Characteristics of hazards induced by extremely heavy rainfall in central Taiwan-Typhoon Herb, Eng. Geol., 58, 191-207, 2000.

Rebetez, M., Lugon, R., and Baeriswyl, P. A.: Climatic change and debris flows in high mountain regions: the case study of the Ritigraben Torrent (Swiss Alps), Climatic Change, 36, 371-389, 1997.

Shin, T. C. and Teng, T. L.: An overview of the 1999 Chi-Chi, Taiwan earthquake, Bull. Seism. Soc. Am., 91, 895-913, 2001.

Stoffel, M.: Debris-flow activity in the Ritigraben torrent (Valais Alps, Switzerland): Will there be less but bigger events in a future greenhouse climate?, in: Landslides and Climate Change, 
edited by: McInnes, R., Jakeways, J., Fairbank, H., and Mathie, E., 2007.

Teegavarapu, R. S. V. and Chandramouli, V.: Improved weighting methods, deterministic and stochastic data-driven models for estimation of missing precipitation records, J. Hydrol., 312, 191206, 2005.

Yu, F. C. and Chen, C. K.: A study on the debris-flow disasters at Feng-Chiou, J. Chin. Soil Water Conserv., 18, 76-92, 1987 (in Chinese).
Zhuang, J. Q., Cui, P., and Ge, Y. G.: Debris flow annual frequency and sediment delivery variations compared to rainfall changed over the last 40 years (Jiangjia Gully, China), 5th International Conference on Debris-Flow Hazards Mitigation, Mechanics, Prediction and Assessment, Padua, Italy, edited by: Genevois, R., Hamilton, D. L., and Prestininzi, A., 173-180, 2011.

Zimmermann, M. and Haeberli, W.: Climatic change and debris flow activity in high mountain areas- a case study in the Swiss Alps, Greenhouse-impact on cold-climate ecosystems and landscapes, Catna Suppl., 22, 59-72, 1992. 